Article

\title{
On What a Religion Is Not
}

\section{Daniele Bertini}

Dipartimento di Studi letterari, filosofici e di storia dell'arte, Università di Roma Tor Vergata, Via Cracovia, 50, 00133 Roma, Italy; daniele.bertini@uniroma2.it

Received: 3 October 2018; Accepted: 25 December 2018; Published: 4 January 2019

\begin{abstract}
Ordinary uses of the terms religion, religious belief, religious matters, and similar seem to give voice to a substantive understanding of what is a religion. Contrary to such uses, empirical research on religions casts more than one doubt on the soundness of a substantive approach. My paper moves from the empirical findings which question the substantive understanding of religious affairs, and explores how not to handle the notion of religion. Particularly, I mean to reject the mainstream received views on religion. At first, I will introduce blocks of empirical evidence in support of the proposition that religious diversity characterizes both the comparison among different traditions and any religious tradition from within. In the subsequent sections I will consider two strategies for characterizing religions. First, I will deal with the phenomenally inclusive view, which is an endeavor of construing religions in conformity with the evidence that religion and similar are ordinarily used in an equivocal manner. Second, I will then approach both strong substantive accounts of religion and the most flexible one I know (i.e., Schellenberg's ultimism). I provide reasons which should incline to reject all of these.
\end{abstract}

Keywords: definitions of religion; substantive vs. functional debate; J. Schellenberg; ultimism

\section{Research Focus and Plan of the Paper}

Religious diversity has recently attracted the attention of a great number of philosophers of religion and scholars in religious studies. This is possibly a plain consequence of the fact that our societies are increasingly multicultural: people from different traditions live side by side, have acquaintance with doctrines which are alien to their own beliefs, and react to the doxastic views of others. Many are challenged by diversity, and require that such a challenge somewhat receives an answer. To make a long story short, debates about how to tackle the incompatibility problem have become more and more relevant for conceptual clarity, argumentative strictness, and philosophical urgency (Quinn and Meeker 2000; Ruhmkorff 2013; Basinger 2018).

Grossly speaking, different religions make different truth-claims. In the religious domain, difference seems to imply incompatibility. For example, a Muslim holds that there is one undifferentiated God alone; a Christian holds that there exists a Trinity of Persons; an Advaita Vedantin holds that nothing like a personal God exists, non-personal Brahman being the only true reality. A very common reaction is that all such beliefs cannot be sound, because if one of these beliefs is correct, the others outcome to be wrong (namely, the truth of one of them excludes that the others can be true either).

A strong assumption is at work here. Different religions endorse different belief systems; that is, each of these conveys a particular world-view, which competes with the others in providing the true understanding of religious matters. The idea is that different religions are incompatible answers to one single problem.

Naturally, this being the case, the situation is puzzling. Apparently, all traditions stand on a par. Neither of these offers conclusive reasons in support of its beliefs, but each of these claims to be the true 
one. Now, if truth excludes falsity, and difference implies incompatibility, the truth of one religion refutes all the other; nonetheless, there are not easy epistemic strategies at disposal for choosing an option over the others. Consequently, philosophical works on religious diversity address which rational moves an intellectually decent believer should pursue in response to a so perplexing state of facts.

My paper originates from a deep dissatisfaction with such an approach. I certainly grant that the philosophical analyses of the incompatibility of different truth claims, the justification of religious beliefs, and the construal of disagreements are instructive and useful. However, in order for such a work to play an explanatory and descriptive role, it requires a different ground, due to many foundational prejudices about the notion of religion which affect the debate. To my view, the problem is that religions are not doxastic competitors dealing with the same contents in different manners. That is, a religion is not a monolithic object which transmits unambiguously a world-view. On the contrary, since diversity is constitutive of any tradition, and any religion grants a plurality of interpretations which bring in the neighborhood of anecdoticity (Bertini 2018), the incompatibility problem cannot be handled in terms of the received framework.

The purpose of my research consists then in providing reasons in support of a negative claim: understanding religions by the popular approaches presently on offer leads to a cluster of difficulties which makes such approaches unavailable to a scholarly work. To my view, this negative claim has however a few important positive outcomes. First, it highlights the need for new ways of accounting for what religions are. Second, it wards off misunderstandings relating to what diversity implies in the religious domain. Third, it cuts off traditional prejudices which prevent us from making sense of religious experiences. Four, it calls attention on the anecdotal particularities of any encounter among adherents to different traditions, and asks that philosophical analysis focuses on such particularities instead of developing highly abstract and universal treatments of systems of beliefs.

My plan is the following. I will start from considerations which question the substantive understanding of religious affairs. My point of departure is not any definite substantive theory. Rather, I will outline what I call a primitive understanding of substantivism towards religion. By primitive I mean something which is accepted before close conceptual scrutiny. The main reason in support of my way of setting the issue is that language inclines people to accept in an unreflective manner that religions are conceptual unitary objects.

Since diversity appears, on the contrary, a constitutive feature of any religious tradition, in the subsequent section I will introduce materials concerning religious diversity, and I will briefly sketch how diversity challenges substantivism towards religion. Such materials provide a short overview of two basic forms of diversity, namely, diversity among different traditions and diversity within one single tradition as well. My view is that approaching religions in reason of diversity suggests that comparisons among different traditions are less rationally justified than ordinarily assumed, and that substantive views of religions may have not empirical evidence in support.

This being the case, I will consider both how religions may be defined in a manner which is respectful of the evidence of the pervasive presence of internal diversity and how reflectively refined substantive theories of religion may be defended. The third section of the paper will deal with the phenomenally inclusive view, which is an endeavour of construing religions in conformity with the evidence that religion and religious are ordinarily used in an equivocal manner. I will sketch the view, consider the objections that J. L. Schellenberg raises against it, and show that the arguments of Schellenberg do not work. In any case, there are conclusive epistemological considerations which attest that the phenomenally inclusive view is not a sound option. Consequently, it should be rejected.

Given that such an option is not alive, I will then come back to substantivism towards religion in the fourth section of the paper in order to explore whether a refined version of the view may vindicate the intuitions framing the primitive conception. I will approach both strong substantive accounts of religion and the most flexible one I know (i.e., Schellenberg's ultimism). I will give reasons which should suffice to reject both.

I will conclude my paper with a short overview of the main outcomes of my approach. 


\section{The Primitivity of the Substantive Approach to Religion}

Ordinary uses of the terms religion and religious seem to give voice to a substantive understanding of what a religion is. A primitive characterization of what substantive refers to can be drawn as follows: religions have a creed (i.e., a sufficiently explicit set of doctrines to which all its practitioners someway adhere); each religion conveys a conceptually unambiguous worldview; adherents to a religion regularly meet for rituals; adherents to a religion make an effort to behave consistently with the way of life which their religion favours; religions have some kind of institutional governance; among the adherents to a religion, some individuals have a sufficient religious expertise for theorizing about the relevant doctrinal topics, and establish what their religion consists in. In conformity with such assumptions, religion is used as a count noun, and different religions are qualified as different options within one and the same domain of discourse.

Evidence for the proposition that substantive views of religions are primitively assumed can be found in everyday experience. In a variety of different contexts-legal, political, ethical, and philosophical - most individuals seem to consider religions as monoliths which face each other as competitors in the achievement of a true understanding of the religious subject matter. Consider a few examples:

- The US Internal Revenue Service defines religious groups and their duties relating income and taxation by means of substantive criteria. Each religious group should meet the following requirements in order to count as a legally recognized unit: having a creed; having a definite form of governance; having regular congregational meetings, having religious education programs, and having a professionally trained ordained clergy (Warner 2008);

- European political debates about Muslim immigration have been recently fueled by nationalist parties which approach immigrants from Islamic countries as undifferentiated individuals, all of them having an identically rigid identity in reason of their religious commitments (Kaya 2014, p. 745 and following). Non-nationalist adversaries of such a view do not reply in terms of rejecting the identity claim (i.e., all the immigrants coming from Islamic countries share the same worldview). Rather, they seem more concerned with defending Islam as a whole from fundamentalist and dogmatic interpretations, by assuming that fundamentalist readings of Islam are residual and based on misunderstandings or strictly political ends.

- The website of the communication giant BBC publishes short introductory notes on many subjects within the section iWonder (http:/ / www.bbc.co.uk/iwonder). Interestingly, the Ethics Guide section approaches most strongly debated ethical issues by providing information on how different religions address them. That is, for each topic (abortion, euthanasia, and so on), these introductory notes sum up the view of worldwide religions (e.g., http:/ / www.bbc.co.uk/ethics/abortion/ religion/religion.shtml). Whoever reads such contents cannot help thinking that each religion has just one view on those ethical matters, and that religions differ also in terms of the ethical view they endorse.

- Most authors dealing with the epistemology of religious beliefs and disagreements adopt an analytic framework by means of which religions are construed in terms of belief systems, and adherence to a tradition in terms of the acceptance of an unambiguous set of core beliefs. Such assumptions affect all of the debate, and are scarcely questioned.

Now, contrary to the ordinary linguistic uses of religion and religious, empirical research on religions casts more than one doubt on the soundness of the substantive approach. Although such research is far from providing conclusive and commonly shared points (think for instance of how the issue of substantive versus functional approach to religion is still a highly debated topic in sociology of religion), my view is that there are enough reasons for distancing the substantive approach to religion. The problem is that, while substantivism towards religion requires that a religion is one unambiguous conceptual object, religious diversity shows that any religion is possibly a plurality of different worldviews assumed in an anecdotal way by their adherents (Bertini 2018). 


\section{Approaching Religious Traditions from Diversity}

The way ahead is tortuous. Religious traditions evidently differ in depth. To a prima facie approach, the proposition that religions do not address comparable experiences, rituals, and ways of salvation or liberation stands on firm grounds.

I will confine myself to the doxastic side of the issue. How is this variety of religious phenomena represented in beliefs? Do beliefs of different traditions have something in common in as much as they are beliefs which have a religious content? Suppose we assume a very relaxed conception of religious belief as a state of mind which has an expressive relationship to either religious experiences or any other kind of religious matters. That is to say, religious beliefs provide a propositional expression of religious experiences or any other kind of religious matters. In other words, religious beliefs are verbal overviews of relevant experiences about religious matters. They claim that things stand in the way in which the verbal overview represents them.

The relaxation of this conception of belief consists in being broad. It is compatible with a plurality of different understandings of what a belief is. Indeed, you can qualify such a state of mind as quantitative assent, qualitative acceptance, faith (believing in), propositional attitude (believing that), or whichever you like. However, it does not matter whether you conceive beliefs in one or the other of these terms. Among many features, the only one in focus here is that religious belief has at least a kind of expressive dependance on some blocks of religious life.

If such expressiveness of religious belief is conceded, doxastic diversity challenges the substantive approach to religions. Languages qualify some social phenomena as religions, and facts about these (beliefs, experiences, rituals, and so on) as religious. Leave aside what kind of objects religions are. Consider only the fact that languages qualify strands of Hinduism, Buddhism, Jainism, Judaism, Christianity, Islam, and many other historical movements (e.g., ancient Greek and Roman polytheism), as religions. Such a qualification determines a categorization of the religious field as a unified domain of discourse (that religion is a count name is evidence in support of the claim). Actually, the use of religion and religious for referring to a multiplicity of different objects involves that each of them is an instance of a religion or has at least a feature which qualifies it as religious. It follows that language-uses incline to a substantive understanding of religions.

Nonetheless, each religion shows particular features. Consequently, if religious beliefs expressively depend on religious life, a difference in experiences produces a difference in what religions and religious mean. For example, how can religions be competing world-views on the same marketplace if they address different subject matters? How can religious traditions be comparable if they present doctrinal and experiential contents which answer ethical ends, epistemic topics, and spiritual needs apparently different in kind?

To mention just a few elementary cases: Is the inner phenomenal frame of performative rituals as the Vedic soma sacrifice structurally similar to the Christian Mass? Does acquiring knowledge in Jainism answer to the same spiritual needs of improving the proficiency in the Torah? Has experiencing enlightenment in Buddhism anything to do with the Sufi dancing which represents the descending movement of light from the transcendent Source of All to this-worldy stuff? Have the mystical paths to the identification with the absolute Brahman anything to do with the ascetic practices of certain strands of Shaivism ${ }^{1}$ ?

1 Notoriously, Mircea Eliade holds that defining religion is a misleading or futile problem, at least at a preliminary stage of inquiry (Eliade 1948). In fact, religions do not share a common feature. On the contrary, they give voice to particular experiences which differ in radical ways. Nonetheless, Eliade claims that religiosity can be traced back to a foundational experience, that is, the revelation of the sacred; and that each myth has an objective meaning, if correctly understood. I agree with Eliade that a refined focus on experience defeats the plausibility of a substantive approach to religions (i.e., religions as unified conceptual objects which address the same content), but I do not accept his viewpoint that myths have an objective meaning. Particularly, I reject his leit-motiv that the correct understanding of a variety of similar symbolisms consists in referring them to their common archetype. To my view, his strategy is to refute substantivism towards religions because of his acceptance of substantivism towards the sacred. As a consequence, he does not actually accept religious diversity, 
Such examples show an evident difficulty concerning comparability. Consider rugby and drama. Taking part in one or the other of these activities requires the actualisation of at least some similar capabilities. For example, both of them are forms of groups activity, and they ask participants to behave in relation to the behaviour of other participants. For each phase of the activity, the appropriate behaviour of a participant consists in a right answer that she gives to the behaviour of others. They both requires the exercise of a joint intentionality by their participants and the acceptance of some social rules. Consequently, rugby and drama have a few structural similarities. Can we say then, that they are different manners of behaviour in respect to the same domain of discourse, i.e., the domain of the practical activities? It would be odd, since rugby and drama differ in the content of the activity, and are the enjoyment of different (kinds of) experiences.

To my view, common semantic intuitions about comparable objects provide an account for such a conclusion: two conceptual objects which and relate to different experiential fields cannot be different items of the same domain of discourse, unless further specified requirements are assumed. I am not arguing that the comparison among objects is legitimate only in case of intensional identity or inherence in the same experiential field. Actually, it is obvious that two objects which differ intensionally and do not relate to the same experiential field can be compared as different items of the same domain of discourse (for example, apples and fishes are both foods, although the former is a vegetable and the latter is an animal). But, when such a comparison occurs, we have extended the original semantic field of application of an object up to the overlapping with part of the semantic field of application of the other. Consider the following situation. Apples are primitively fruits, and fishes are primitively animals. It might be the case that I have never realized that animals can be food. Therefore, an apple is a vegetable and a food to me, while a fish is simply an animal. The semantic field of application of apples is both vegetable and food kinds (as many other things I now overlook); the semantic field of application of fish is animal kinds. Suppose I have never eaten an animal because there are not edible animals in my environment. I might begin to eat fish if I discovered an edible fish, but I should learn that such fish is an edible one. Therefore, learning that a fish may inhere in the domain of discourse of food kinds implies that I extended the semantic field of application of the notion of fish from the field of animal kinds up to the overlapping with the field of food kinds. Such extension falls under some relevant specifications. Conclusion follows. I need to specify further requirements in order to extend the semantic field of application of a conceptual object to another domain of discourse.

This being the case, inter-religious diversity fosters a degree of scepticism toward the prima facie assumption that religions are conceptual objects belonging to the same domain of discourse: religions differ intensionally, and the relaxed conception of beliefs raises a number of doubts about the claim that religions can be qualified as object of a unified domain of discourse. Naturally, it can be that religions are in fact conceptual objects belonging to the same domain of discourse. But if I want to say this, I need some reasons which specify the requirements for legitimately comparing intensionally different religious experiences.

Anyway, a further complication comes along. It is plainly evident that each one of these phenomena is contextualized in a long term history which makes religious life different at different times. For example, liturgy has a clear developmental history: early Christians celebrated the Mass differently from medieval Christians, and these from contemporary ones (Grillo 2005; Mazza 2010; Mazza 2012). Evidently, the claim that religious traditions depend on the temporal changeability of social and cultural contexts holds for any other religion too, religious traditions being historical facts.

nor recognises the constitutive role of internal diversity for any tradition. On the contrary, according to him, each sound religion is a particular revelation of the same type of symbolisms which appear in different traditions and refer to the same archetypes. His history of religions is indeed a historical typology of the different symbolisms which any sound religion accepts. As such, his views can be categorised among the scholarly substantive approach against which I argue in the fourth section of the paper. 
Moreover, the emergence of difference within one and the same tradition affects religions also from a synchronic standpoint. Believers which belong to the same denomination and live in different contexts commonly experience their religious life in a different manner.

The following list of paradigmatic cases is a bit random, but particularly suited for highlighting what I mean:

- the recent declaration of the cardinal Robert Sarah on what ingredients of bread make the Eucharist efficaciously imparted testifies that a plurality of different materials is commonly used within different contexts (Congregazione per il Culto Divino e la Disciplina dei Sacramenti 2017);

- Jains in the USA ordinary use Hindu facilities in order to celebrate rituals, but such things are quite unusual in an Indian context (Long 2014);

- Muslims all over the world enjoys a context-dependent experience of Islam, this being practically constituted as a local way for pursuing global ends (Cesari 2014, pp. 9-11; Montgomery 2015, pp. 238-39);

- While many traditional Hindus which are devout to Shiva and live outside India inform their rituals with a mystical attitude toward foundational places such as the Chidambaram Temple (this means that sound rituals allow a believer to mystically access the temple), Hindus which take part in Shaivist rituals there do not attribute to these rituals a comparable meaning, and seem to attribute relatively little importance to the Temple (Bellentami 2013, pp. 115-16);

- The Liturgical assembly of the second month is an important public Buddhist ritual performed in Japan. Three different kinds of participants make a radically different experience, and understand the ritual in potentially incompatible terms: occasional attendees expect to receive a few esoteric benefits and protection from evils by paying homage to the deity in the hall and without being concerned with the ascetic practices of the monks (occasional attendees ignore the long preliminary preparation to the ritual and do not have any knowledge of the different steps involved, that is, they behave mainly as witnesses); focused attendees enjoy an uplifting condition and a spiritual improvement subsequent to their stay in the neighborhood of the monks (focused attendees have good knowledge of the ritual, listen to the recitation of the precepts, and spend the night in silence or by doing some other meditative practice); monks enjoy a deep ascetic and transformative experience of liberation (Dolce 2010, pp. 454-56).

All these examples point at the same fact: differences in linguistic, sociological, and cultural contexts make a difference in liturgy and religious life too. Let me refine a little such a proposition. I define scope of belief the relation between the content of belief and the semantic context which determines how to interpret it. For example, all Christians believe that the Eucharist is the climax of the Christian ritual life (E). This means that each Christian holds that the content of the proposition that the Eucharist is the climax of the Christian ritual life is the case in relation to a semantic context which specifies how such content should be determined. Now, semantic contexts change. The early Christians celebrated the Eucharist in order to keep alive the memory of Jesus while they were waiting his coming back; contemporary Christians celebrate the Eucharist in order to renew the Holy Covenant with God by taking part in his assembly; mystical Christians celebrate the Eucharist in order to become one with Jesus Christ; and so on. They all believe E, but they give a different meaning to it.

In light of these notions, what a Christian holds when believing E should be specified in terms of the semantic context for understanding E. That is to say that the scope of $\mathrm{E}$ is not the same for all Christians believing E: for early Christians E should be understood as an apocalyptic belief, for contemporary Christians $\mathrm{E}$ is a belief about how to adhere to Christianity, for mystical Christians E is a mystical truth.

The diachronic and synchronic difference among beliefs of a religious tradition shows that, even if all coreligionists accepted the same set of core beliefs, elements of such a set would differ in scope.

Consequently, given that religious beliefs have some kind of expressive dependance on one or the other blocks of religious life, it results something along the following lines: 
- religious beliefs of different traditions address contents which possibly concern to different domains of discourse;

- religious beliefs of one and the same tradition address different contents which, although possibly concerning the same domain of discourse, actually show a context-dependent diversity of scope.

As a consequence, religious diversity challenges the rationality of substantivism towards religions. On the one hand, intra-religious diversity is constituent of any religion. Indeed, if the content of a religious belief may vary over different semantic contexts in reason of the scope of the belief, there is no unambiguous set of propositions which all coreligionists hold to be the case. Now, empirical research on religious traditions testifies that diachronic and synchronic diversity in scope characterizes beliefs of all traditions. Consequently, models of religions construed in terms of substantive criteria appear basically naïve. For the other, if my relaxed conception of religious belief is conceded, inter-religious diversity provides evidence in support of the claim that the religious domain of discourse cannot be understood in a substantive manner. Suppose I stipulate that a trans-contextual notion of religion and religious matters defines religion and religious matters as concepts which apply to different socio-cultural contexts according to at least one relevant common feature (e.g., if $\mathrm{x}$ is a religion, $\mathrm{x}$ possesses the feature $\mathrm{P}$; if $\mathrm{x}$ is a religious matter, $\mathrm{x}$ possesses the feature $\mathrm{P}$ ). Evidently, the substantive approach to the religious domain of discourse is trans-contextual because it identifies features which all religions would share. But, beliefs of different traditions address contents which possibly concern different domains of discourse. As a consequence, the prima facie assumption that religions and religious matters do not vary over different contexts should not be justified. Therefore, any starting point which moves from a trans-contextual notion of religion and religious matter will result evidentially unwarranted. My conclusion is that substantivism could turn out to be the right option in accounting for religions. However, such a possibility cannot be assumed primitively, but should be the outcome of a foundational inquiry. An assessment of the notion of religion is then required.

\section{The Phenomenally Inclusive View}

Two main options are available. I name the first the phenomenally inclusive view (PI). According to PI, the concept of religion can be qualified as a family resemblance concept (FRC). Wittgenstein introduces FRCs as follows: "Consider for example the proceedings that we call 'games'. [ ... ] What is common to them all?-Don't say: There must be something in common, or they would not be called 'games' - but look and see whether there is anything common to all.-For if you look at them you will not see something that is common to all, but similarities, relationships, and a whole series of them at that. $[\ldots]$. ... the result of this examination is: we see a complicated network of similarities overlapping and criss-crossing: sometimes overall similarities, sometimes similarities of detail. I can think of no better expression to characterize these similarities than 'family resemblances', for the various resemblances between members of a family: build, features, color of eyes, gait, temperament, etc., etc., overlap and criss-cross in the same way" (Wittgenstein 2001, pp. 27-28 E).

PI consists in considering the different religions as elements of an informal web of local similarities. For example, suppose $\mathrm{w}, \mathrm{x}, \mathrm{y}$, and $\mathrm{z}$ are four different religions. They have the following the properties:

- $\quad \mathrm{w}$ has properties $\mathrm{P}^{1}$ in respect to the domain $\mathrm{K}$ and $\mathrm{Q}^{1}$ in respect to the domain $\mathrm{J}$;

- $\quad x$ has properties $\mathrm{Q}^{\mathrm{i}}$ in respect to the domain $\mathrm{J}$ and $\mathrm{S} 1$ in respect to domain $\mathrm{L}$;

- $\quad \mathrm{y}$ has properties $\mathrm{Pi}$ in respect to the domain $\mathrm{K}, \mathrm{Si}$ in respect to domain $\mathrm{L}, \mathrm{R}^{1}$ in respect to domain I;

- $\quad z$ has no properties in respect to K, J, and L, but has Ri in respect to domain I.

This being the case, $\mathrm{x}$ resembles $\mathrm{w}$ in respect to $\mathrm{J}$, but not for all respect. Indeed, $\mathrm{x}$ lacks a property in the domain $\mathrm{K}$. Now, $\mathrm{y}$ resembles both $\mathrm{w}$ and $\mathrm{x}$, but not for the same respect: $\mathrm{y}$ resembles $\mathrm{w}$ in respect to $\mathrm{K}$, and resembles $\mathrm{x}$ in respect to $\mathrm{L}$, but lacks properties in respect to $\mathrm{J}$, which both $\mathrm{x}$ and $\mathrm{y}$ have. Finally, $\mathrm{z}$ does not resemble $\mathrm{w}$ and $\mathrm{x}$, because lacks properties in domains $\mathrm{K}$, J, or L; nonetheless, $\mathrm{z}$ is still a religion: it resembles $\mathrm{y}$ in respect to $\mathrm{I}$, and $\mathrm{y}$ is a religion. 
Let:

w stands for Literalist Shaivism

$x$ stands for Advaita Vedanta Hinduism

y stands for Roman Catholicism

$\mathrm{z}$ stands for Tibetan Buddhism

K stands for Theism

J stands for Veda tradition

I stands for Religious leadership

L stands for Transcendence

Then:

- Literalist Shaivism resembles Roman Catholicism in respect to theism (they are both theist religions);

- Literalist Shaivism resembles Advaita Vedanta Hinduism in respect to the Veda Tradition (they both accept the Vedic body of literature);

- Advaita Vedanta Hinduism resembles Roman Catholicism in respect to transcendence (they both assume that the ultimate reality is absolutely transcendent);

- Roman Catholicism resembles Tibetan Buddhism in respect to Religious leadership (they both have an ordained magisterial authority);

- Literalist Shaivism does not resemble any religion in respect to the absolute transcendence of the ultimate reality and to having a religious leadership;

- Advaita Vedanta Hinduism does not resemble any religion in respect to theism and to having a religious leadership;

- Roman Catholicism does not resemble any religion in respect to accepting the Veda tradition;

- Tibetan Buddhism does not resemble any religion in respect to theism, to accepting the Veda tradition, and to the absolute transcendence of the ultimate reality.

Such a construal allows for an understanding of religion which is respectful of the factual diversity of religious traditions. Actually, the main force of PI consists in the capability to categorize different phenomena under the heading religion without postulating empirically non-observable common features. Particularly, PI takes seriously the possibility that religion and religious are ordinarily used in an equivocal manner.

Leading proponents of PI are P. B. Clarke and P. Byrne (Clarke and Byrne 1993, pp. 7-13) and Hick (2004, pp. 3-5). Notable critiques of Clarke's and Byrne's use of FRC are advanced by Schellenberg (2005, pp. 7-12). He makes two claims: (a) Clarke and Byrne are not consistent in construing religion in terms of FRC; (b) the notion of religion is not a FRC because it is possible to identify at least a feature which all religions do oppose, and by starting from such a feature, make some steps toward a positive conceptualization.

Claim (a) is not conclusive, and is not particularly relevant either. Unless Schellenberg is able to prove that the notion of FRC is used by Clarke and Byrne inconsistently in reason of the logical impossibility to use it in a consistent manner, in case (a) hits the target, (a) would achieve no better result than showing how not to employ FRCs to approach religions. Naturally, given the absence of general reasons against the opportunity to use FRCs to approach religions, it does not follow from (a) that any use of FRC to approach religions is unsound.

Claim (b) is a manouvre to close the gap between the particularity of problems regarding Clarke's and Byrne's use of FRC and the general view that any use of FRC is unsound. A disqualifying feature is any feature whose possession prevents a thing $\mathrm{x}$ from being a token of some kind $\mathrm{P}$. It is not simply that such being does not have the relevant disqualifying feature: for any $\mathrm{x}$, it holds that being a $\mathrm{P}$ is a matter of not having the disqualifying feature.

Consider the feature of smoking more than twenty cigarettes a day in respect to the concept PROFESSIONAL ATHLETE IN HEAVY LOAD SPORT (I understand heavy load sports as running, 
swimming, and biking competitions on long distances) $)^{2}$. It seems reasonable to assume that if an individual smokes more than twenty cigarettes a day, such an individual has not any chance to take part in the Olympic Games, World Games, or other international competitions in heavy load disciplines. Now, a pro athlete should be able to participate to Olympic Games, World Games, or other international competitions. I am not claiming that if she does not participate, she is not a pro athlete. Simply, she should do whatever she can in order to participate: if her life conduct prevents necessarily her from taking part to professional sport events, and she is not willing to change, then she is not a pro athlete. Conclusion follows: an individual which smokes more than twenty cigarettes a day cannot be counted among professional athletes.

Evidently, a similar assumption does not concern a feature that all professional athletes do not have in reason of their being something in general. For example, in reason of their being mammals, all professional athletes do not lay eggs. But, not laying eggs is not a disqualifying feature for PROFESSIONAL ATHLETE IN HEAVY LOAD SPORT because it has nothing to do with being a professional athlete: it is unable to distinguish—say—between professional athletes, non-professional athletes, and other mammals. On the contrary, smoking more than twenty cigarettes a day provides a positive criterion to decide whether an individual does not belong to the extension of PROFESSIONAL ATHLETE IN HEAVY LOAD SPORT, and such a criterion is related to being a professional athlete in heavy load sport: smoking more than twenty cigarettes a day necessarily makes it not possible that an individual does high level performances in heavy load sports. Consequently, not smoking more than twenty cigarettes a day is a requisite that all professional athletes in heavy load disciplines must satisfy. In other words, smoking more than twenty cigarettes a day is able to identify unambiguously a feature which necessarily all the members of PROFESSIONAL ATHLETE IN HEAVY LOAD SPORT do not have because of their being professional athletes in heavy load sports; and this capability makes it a disqualifying feature for the concept.

Now, if a disqualifying property for being a $\mathrm{P}$ can be defined, then all $\mathrm{x}$ which are Ps have in common at least a substantive feature; i.e., not having the relevant disqualifying feature. A substantive feature for falling under the extension of a concept $\mathrm{P}$ is then a property that all Ps have in reason of their being $\mathrm{P}$. That is to say, being $\mathrm{P}$ implies that $\mathrm{x}$ has at least one of the relevant substantive features: if $\mathrm{x}$ is a $\mathrm{P}, \mathrm{x}$ has at least a substantive feature for being a $\mathrm{P}$.

Schellenberg's strategy for defending (b) consists in showing that a disqualifying feature for being a religion can be defined. If this were the case, all religions would have a common substantive feature. Consequently, the notion of religion could not be approached in terms of FRCs. Unfortunately, disqualifying features cannot do the work which Schellenberg claims. Therefore, (b) remains unsupported.

That's why. Suppose that quantitative research on performances in heavy load sports attests that, beyond a positive threshold, lack of results linearly depends on high levels of stress. Further empirical investigations show that smoking hard (more than twenty cigarettes a day) constitutes a method to minimize a high level of stress. As a consequence, researchers in sport matters begin to develop a procedure for maximizing the beneficial effects of hard smoking on stress, while minimizing the dangerous consequences on performances. After some time, a technique which is not considered doping is ready to be used (I imagine such technique has to do with the consumption of a few markers which locate and destroy toxins deriving from hard smoking). A similar method does not improve the performance by increasing some skill, but brings back the circulatory system to its natural functioning. Suppose that after that some athletes found it useful, most of them understand its benefits, and began

2 In order to provide a non controversial counterexample to the plausibility of the notion of disqualifying feature I will reason from a domain of discourse other than the religious one. Making the case within the latter may indeed raise a number of interpretive issues that obscure the validity of the counterexample. Once this is established in its own right, I will then show that what is relevant to it, is relevant to the religious domain too. 
smoking hard. This being the case, smoking more than twenty cigarettes a day is not a disqualifying feature for a PROFESSIONAL ATHLETE IN HEAVY LOAD SPORT anymore.

Now, what such a story highlights is that the requirements for being a pro athlete change in time, due to the contingent nature of any sport practice. Consequently, there is no usefulness in defining disqualifying features here. They cannot serve to identify whether an entity does not belong to the extension of a concept, and determine accordingly that entities which do belong to it, do not have the disqualifying feature.

Evidently, religions are similar to the case of PROFESSIONAL ATHLETE IN HEAVY LOAD SPORT. Religious traditions are historical objects which have extended in time over millennia. Within one and the same tradition, both essential and peripheral religious notions may change. There is always a sort of contingency in what a community believes. For example, while at their beginning many religious traditions incline toward a literal reading of their sacred texts, they subsequently shift toward a non-literal understanding of these. Naturally, giving a literal or non-literal meaning to a religious narrative provides very different contents to the relevant beliefs. How can I know what meaning the beliefs of my tradition will have in the future? This being the case, definitions of disqualifying features cannot identify substantive features of religions (it might be that the defined disqualifying feature was not a disqualifying feature in the past and will not be a disqualifying feature in the future). Conclusion follows: the definition of a disqualifying feature is not a reason against the characterization of religions in terms of $\mathrm{FRCs}^{3}$.

Defenders of (b) may reply that any disqualifying property takes a picture of how to use correctly a concept at present. That is to say, when a theorist defines a disqualifying property for being a $C$, she says something about the way a concept is at present employed within a variety of linguistic practices of a community. Therefore, not having the disqualifying property says something substantive about what the community believes about being a C. It is not important whether something will change in the future. At present a disqualifying property for being a $C$ provides essential criteria to be counted among Cs.

Unfortunately, such a reply does not hit the target, at least when contingent matters are the definienda. Being a professional athlete in heavy load sport, as being a religion, is definitely a matter of fact. As such, it is a contingent affair. Whichever property I may define, I will never know if it is a disqualifying property for the notion of PROFESSIONAL ATHLETE IN HEAVY LOAD SPORT, because contingency is constitutive of being a pro athlete. The same holds for RELIGION.

All the matter at dispute is exactly this. While Schellenberg claims that it is possible to define properties which are necessarily related to whether an entity belongs to the extension of a concept, PI theorists contend that such a definition is not possible because identifying a religion is a completely contingent affair. Now, the case of PROFESSIONAL ATHLETE IN HEAVY LOAD SPORT supports the claim that it is not definable a disqualifying property for contingent objects. Religions are contingent objects. Consequently, a disqualifying property is not definable for religion. The best I can do by the notion of disqualifying feature is to map the linguistic use of a term for a community in a given time.

3 This is particularly true of Schellenberg's example of a disqualifying feature for religion: "It seems, most obviously, that someone whose dominant and persistent view was that nothing in life has meaning or value could not be religious. [Such a disqualifying definition] ... places a clear onus on representatives of the family resemblance approach to come up with possible examples of religion that include the (allegedly) disqualifying feature: [...] Show us evident examples of religion that involve no goal oriented behavior, or that are completely nihilistic, or that remain entirely within the mundane realm" (Schellenberg 2005, pp. 10-12). Now, Nikaya Buddhism and (at least to a certain degree) Zen Buddhism are not goal oriented (they are methods to detach individuals from acting in view of the pursuing of positive ends); many versions of Buddhism and Advaita Vedanta Hinduism are completely nihilistic (they states that the ultimate reality is void or non intentional awareness of nothing); ancient Greek and Roman religions remain entirely within the mundane realm. I imagine that a reply to the claim that Nikaya Buddhism and Zen Buddhism are not goal oriented is possibly to say that they have a positive goal: it is to free individuals from acting in view of the pursuing of a goal. In my view, such a reply means playing with words. If you systematically look for the liberation from acting in view of the pursuing of a goal, and you finally achieve it, then your behavior cannot be said to pursue a positive goal. Your goal is to learn to have no goal anymore, that is, once you have learned how to have no goal anymore, you have no goal anymore. End of the story. 
But, since religious traditions extend in time over millennia and change at the passing of time, such an enterprise will not give any essential information about what that religion is.

Anyway, although PI theorists are certainly right in approaching religions by focusing on equivocation and difference, PI should be rejected for epistemological reasons. My argument is the following. Hick claims that dealing with the notion of religion in terms of FRCs allows to display the relational links among different social movements. Resemblances in some formal respects construe a ramified network where some movements occupy near positions, and others distant ones. As Hick writes:

This understanding of the concept also enables us to locate the secular faith of Marxism as a fairly distant cousin of such movements as Christianity and Islam, sharing some of their characteristics (such as a comprehensive world-view, with scriptures, eschatology, saints and a total moral claim) whilst lacking others (such as belief in a transcendent divine reality). Accordingly, when within what we may call the Oxford-Larousse-Brockhaus linguistic world we are speaking of the more central members of the religious family we usually exclude Marxism, although when speaking more broadly we include it. (Hick 2004, p. 5)

My claim is that a similar conception is useless in social sciences, because it is unable to design informative quantitative research. Consider different social phenomena as a religion-say Christianity-Marxism, and being a strongly committed supporter of a football team. There are some evident functional similarities among these movements: they all answer a psychological need to construe personal identity in collective terms; they all provide individuals with ends which transcend their ordinary daily life; they all put a rest to the will by subduing individuality to the adherence to a group; and so on. It is a matter of fact that such similarities produce a formal resemblance in the social movements under consideration. For example, religions, Marxism, and hooligan movements show to rely on strongly emotive accounts of foundational events, possess a highly structured hierarchy of participants, and ask individuals to conform their own behaviour to group standards. In the PI theorist's terminology, functional similarities create a knot in the web of resemblances which constitute a FRC.

Consequently, if a sociological or psychological inquiry addressed one of these issues in relation to Christianity, Marxism, or being a strongly committed supporter of a football team, it would not be in a position to discriminate among the different social movements. What a similar research could accomplish is to determine which score each movement achieves in relation to different measurable items, but it could not interpret empirical findings by relating them to the evidence that one movement is a religion, another is a political organization, and the last is a free time practice. Actually, since Christianity, Marxism, and being a strongly committed supporter of a football team are compared in terms of their formal similarities, and such similarities are due to the inclusion in the same network of social phenomena, quantitative inquiry can merely sketch an image of how some features vary within different actualisations of the same social functions. For example, such an inquiry lacks any capabilities to account for the reasons why one movement scores better than others in providing individuals with a firm personal identity or developing a highly structured hierarchy.

Such a difficulty is obviously a hard one to manage, because it leads to treating what should be distinguished as variations of identical social attitudes. Functionally-driven quantitative inquiries are shown to be unable to achieve any interpretative power toward their subject matter. Consequently, while they may have some motives of interest in reason of the fact that they register how different social movements (among which religions should be classified) make themselves actual, they report no definite information about what such movements are and why they work as they do (Berger 1974).

All considered, PI cannot foster any kind of informative quantitative inquiry, nor give an account for religion consistent with good epistemological research practices in social sciences. My conclusion is then that PI should be rejected. 


\section{The Substantive Account for Religion}

There are two kinds of substantive views of religion, i.e., confessional and philosophical. The confessional substantive account (CS) starts from what a religion is held to be within a tradition. Accordingly, CS includes in religions all which meets the requirements of such a definition and excludes all which does not match to it. Notable examples of CS are J. Ratzinger's definition of Christianity in terms of reason-driven practices (Ratzinger 1986), M. Legenhausen's definition of Islam in terms of uncorrupted Revelation (Legenhausen 1999), Sarvepalli Radhakrishnan's definition of Hinduism in terms of mystical experience (Radhakrishnan 1957), and Daisetz Teitaro Suzuki's definition of Buddhism in terms of personal enlightenment (Suzuki 1964).

What is common to all these is that, although they are ready to recognize that there is a variety of religions, they hold that not all objects that ordinarily are counted as religions are in fact ultimately religions. According to such views, just one tradition satisfies all the relevant criteria to be actually a religion, the others failing to meet authentically the relevant requirements. Consequently, they can accommodate the claim that, as a matter of fact, the terms religion and religious apply to a multiplicity of different objects. But, they deal with such a claim by saying that there is one true religion, to which the terms religion and religious correctly apply, and there are many defective actualisations of the true religion, which resemble it in some respect and to which the terms religion and religious unsoundly apply in an equivocal manner.

There are three main problems here. Firstly, CS is not able to categorize as religions what seem to be religions indeed. For example, according to the view that religious belief is to have faith in someone, many Jews, Christians, and Muslim are not at ease with the idea that polytheism, animism, and pantheist systems of belief are good candidates to be a religious option. As a consequence, ancient Greek and Roman religions and the religious systems of most ethnologic groups are not classified within religions at all; rather, they are said to be mythologies. From such a viewpoint, mythologies resemble religions in some respect, but they are characterized as a way to establish a non-genuine religious relationship with their objects. Particularly, mythologies think of the divine realm as a complex architecture of natural powers, that human beings can handle and have at their disposal. Consequently, mythologies are judged to be the outcome of the exercise of a fully cognitive attitude toward the world. They are not expression of love, gratitude, and submission to the religious object of a faith.

Evidently, such a claim is not supported by any evidence: literary, philosophical, and historical sources attest that ancient Greeks and Romans (and the same holds for the members of ethnologic groups) did hold religious beliefs in ways that are fully comparable to Jewish, Christian, and Muslim ones. This being the case, CS lacks taxonomical virtues.

Secondly, CS cannot take seriously in consideration the idea that believers adhering to different traditions are religious peers. Actually, if you hold that someone is not soundly engaging in a practice, you judge her in terms of making a mistake or being guilty of some misunderstandings (Plantinga 2000, p. 182). That is to say, evaluating religiosity of others from the standpoint of CS, involves understanding it as a committal toward something which, although individuals engaging in the practice do not think of it as wrong, it is in fact wrong. Therefore, a similar evaluation shows to be a party in a religious disagreement (about what is a religion).

Now, there is a widespread consensus that religious disagreements are cases of deep disagreements (Feldman 2007; Bogardus 2013). The contemporary epistemology of disagreement is a highly fueled field of theoretical discussion. Few views are shared among the community of scholars. Possibly, the only one is the claim that deep disagreements should be approached from the standpoint that disagreeing individuals are peers (Feldman 2006; Christensen 2007; Elga 2007; Bogardus 2009; van Inwagen 2010; McKim 2012). Consequently, since CS is a party in a religious disagreement, and CS is not able to consider individuals dealing with the content matter of such a disagreement as peers, CS turns out to be an unsound manner to face the problem of religious diversity, and violates scholarly constraints on how to handle a disagreement. 
Thirdly, it follows from the previous point that CS is not in the position to favour an effective interfaith dialogue. If I say that you are wrong in doing what you to do because you are trying to do as me but you are not sufficiently good in accomplishing your task, you probably stop listening to me and treating me as an interlocutor. Engaging in a dialogue requires that you are ready to learn from others, consider them as proponents of challenges to your beliefs, and respect them as epistemic agents (Bertini 2018). In other words, you should grant that comparing your views with opponents is a very important thing (for you). Such a respectful attitude toward the epistemic capabilities of others is a requirement of any dialogue. CS cannot satisfy such a requirement. Therefore, CS should be rejected (at least by all those who think that interfaith dialogue is a positive and mandatory religious practice). The point of the matter is that people engaging in interfaith dialogue hold that a positive confrontation with the viewpoint of others makes them grow in learning, both epistemically and existentially. Independently of whether adherents to different traditions are able to settle their disagreements, their mutual and active acquaintance produces an increase in wisdom, respect, and toleration. Moreover, they acquire more strongly justified beliefs and implement relevant ideas within their belief system.

In light of these observations, CS is of little appeal. I thus come to considering the second manner to account substantively for the notion of religion. A scholarly substantive account (SS) aims at grasping the nature of religion by comparing different traditions and abstracting accordingly their recurrent features. The subsequent move is to construe religions by relating their recurrent features to a historico-genealogical, phenomenological, or linguistic and structural order. SS is the typical framework of inquiries on religion which has been advanced during the most part of the last century by theorists adhering to the school of history of religion, phenomenology of religion, or cultural anthropology.

These inquiries provide an impressive body of empirical findings and interesting contributions to the debate on how to define the notion of religion, but they are defective because characterize the evidence that religion and religious are employed in an equivocal manner by relying upon the obscure notion of analogy (Bianchi 1975, p. 6 and following). Shortly, SS is based on the following building blocks: (a) acknowledgement that religions are actually different to such a degree to constituting a problem for a substantive approach to them; (b) discrimination of whether a certain social movement is a religion by focusing on those similarities among different traditions which incline individuals to extend the application of the terms religion and similar from one tradition to another; (c) evidence that such extension presupposes internality to a tradition (that is, each extension of the use of religion and religious from a tradition to another is expression of a context dependent viewpoint). From (a), (b), and (c), the SS theorist concludes that resemblances among religions allow a trans-contextual use of religion and religious because of the fact that religions show to be different actualisation of analogous trans-contextual features.

Independently of the general difficulty that analogical predications are quick ways to postulate identity in face of diversity, each version of SS should identify some core common elements among religious traditions. The more such elements are determined in content, the more they are subjected to objections and counterexamples.

For this reason, I will now address the most general construal of SS, namely, the construal of SS which is mostly indeterminate in content. My intuition is that if even such an indeterminate view is defeated, then there is no room for any kind of SS.

Schellenberg defines ultimism as a view that each religion someway entails and fills out. Ultimism is the claim that there is a reality metaphysically and axiologically ultimate (representing the deepest fact about the nature of things and also unsurpassably great), in relation to which an ultimate good can be attained. This equals to saying that there is an ultimate salfivic reality.

Schellenberg's account of religion consists of two different steps. Firstly, he defines four general features of religiosity. Such features characterize all religions, but, although they provide necessary conditions for being counted a religion, they are not able to specify a sufficient one. Thus, they need refinements and improvements (Schellenberg 2005, pp. 12-22). Secondly, he argues that such features 
are captured by the conjunction of two more technical claims, which can now be defended in such a technical form. Schellenberg's main thesis is that the conjunction he argues for in this second step establishes a generic view (generic ultimism) which all religions entail by providing an elaborated content in terms of doxastic representations of the ultimate reality and how it is salvific (elaborated ultimism) (Schellenberg 2005, pp. 36-37).

The four essential features of any religion are the following:

(1) frequent thoughts of a transmundane reality; (2) an emphasis on a significant good, for oneself and others, that may be realized through a proper relation to this reality; (3) the cultivation of such a relation; and (4) a disposition or tendency, when attending at matters in which they are implicated, to-as I shall put it—-totalize or ultimize in some ways the central elements of features (1) to (3). (Schellenberg 2005, p. 12)

Here is a short commentary on how to unpack Schellenberg's characterization. Although transmundanity is spelt out in terms of beyondness in respect of mundanity, the expression transmundane reality has little to do with the notion of transcendence. Gods who belong entirely to the realm of mundanity (as ancient Greek and Roman deities) can be said to be objects of a transmundane thought indeed. Actually, the opposition between mundane and transmundane should be understood by the notion of what is ordinary. A mundane reality is, while a transmundane reality is not, the object of ordinary perceptual and epistemic practices. Inhering in the former group means that, independently of how you may make an inventory of the items of reality (e.g., objects, events, states of facts, states of affairs, or whichever else you adopt), such items are the easily accessible contents of our ordinary experiences. Therefore, transmundanity is not an ontological feature. It is nothing more than the core nature of what is important in reality. What qualifies such a core nature as transmundane is simply that such a core nature is hidden to everyday business, concerns, and activities.

The second and the third features do not present particular problems. On the contrary, some words are to be spent on the most important of the features under consideration, that is, the fourth. Schellenberg defines ultimazing as a tendency to consider the object of (1), the good of (2), and the practice of (3) as ultimate. Ultimazing is a matter of engaging in a limit-removing behaviour. According to (4) then, religious individuals deals with the objects, the ends, and the actual form of their faith, as something unlimited in respect to the realm of existence. Religiosity does not have to do with some peripheral entities, with objects of a specific ontological domain, or with something that can be bracketed. Rather, religiosity concerns the whole of life, it is what eminently confers a meaning to it, and is a method to become acquainted with something existing unlimitedly within every different context.

The conjunction of claims which provides a technical definition of religion is the following:

Let me put my cards on the table right away. In my view, such a definition would make ultimization central. It would say, to be specific, that "S is religious (or exhibits religion)". It should be viewed as synonymous with the conjunction of the following propositions: (1) $\mathrm{S}$ takes there to be a reality that is ultimate, in relation to which an ultimate good can be attained; (2) S's ultimate commitment is to the cultivation of dispositions appropriate to this state of affairs". (Schellenberg 2005, pp. 22-23)

Now, there are two main problems which make ultimism unable to provide a sound definition of religion. Such a problem relates to the fact that the four general features of religiosity which Schellenberg lists in his first step do not capture any essential feature of religions. As this regard, it should be noticed that Schellenberg does not claim that ultimism is to be spelt out in such terms. Nonetheless, while he does not endorse a definition of religiosity in terms of the conjunction of the four features of religiosity with which he deals in his first step, he holds that the definition of religiosity he provides in the second step satisfies such features, and captures them in a form that it is fit for the theoretical needs of philosophers of religion. For a side, the four general features deploy how to read the conjunction of claims (1) and (2); namely, they are the meaning of the conjunction. For the other, 
the conjunction focuses on the core content of the four general features by making explicit what renders them necessary. Consequently, Schellenberg identifies a criterion by which necessary conditions for being a religion are made effective; that is to say, the conjunction consists in the addition of a sufficient condition to the four general features.

In his view this argument applies to philosophy only. His purpose in defining religion is indeed to set forth a workable way to handle religious matter from a philosophical viewpoint. He does not think that his theorizing should be defended within all disciplinary fields related to religion. In any case, such a modest approach does not appear to be of any usefulness within a research framework. Knowledge is one single thing: if a notion is unsound in general, it cannot be useful in any determinate research domain of discourse; if it is sound in general, it establishes relevant features for all determinate research domains of discourse.

The sufficient condition which is introduced by the technical account given by the conjunction is the centrality of the process of ultimization: a tendency to ultimazing (frequent transmundane thoughts, the search of a good, the cultivation of a relationship with the object of transmundane thoughts, and the limit-removing behaviours) is the grounding of any religion. Consequently, the four general features plus the technical definition of ultimization provide the content of what Schellenberg understands with religion and similar. An evident reason in support of such a reading is that the elucidatory remarks which he develops in the second step of his endeavour of defining religion concern how to understand the four general features in terms of the notion of ultimization (Schellenberg 2005, p. 25 and following).

What are the problems with Schellenberg's account? First, ultimism poorly fits with the phenomenology of many religious experience. My view is that there are contents of religious experiences which are not transmundane (according to the way Schellenberg employs the term), being completely mundane in fact ${ }^{4}$. Consider ancient Greek and Romans deities. For a side they certainly are extraordinary entities. Nonetheless, they are not extraordinary because they subsist in a realm which is beyond the daily activities of human beings, or fall outside everyday concerns. On the contrary, they are extraordinary because of a fully mundane feature they possess, that is, their superhuman power to act within ordinary practical fields of existence (e.g., citizenship (Finley 1963; Murray 1993), agriculture (Mantzillas 2016), house-governance (Vernant 1996), etc.). Such powers are overtly evident constituents of ordinary experiences. They are something which relates to common everyday actions, and are present in almost all respect of the life of ancient Greeks and Romans. Their presence in human life is as evident as anything which is natural (Vernant 1962; Bremmer 1999; Snell 2009).

Two notable ancient sources describe such familiarity with Gods, omnipresence of the divine realm in daily business, and ability to manipulate deities as the most evident features of Greek religion. Plato attacks the traditional religiosity of Athens in Euthyphro. Shortly, Socrates' charges his interlocutor of acting instrumentally toward the Gods, in reason of his adversary's belief that whoever performs correctly a sacrifice establishes a direct relationship with the relevant deity, and manage a mundane power for her own sake. (Plato, Euth., 14e-15a). What Socrates complains here is that Athenians seem unable to approach Gods as mysterious entities which are worthy of a holy respect. On the contrary, Athenians think of deities as natural things at their disposal (Ballanti 2014).

The Apostle Paul preaching at the Areopagus agrees with a similar diagnosis of Athenians (Acts, 16.16-34). Urged by some Stoic and Epicureans philosophers to give a short account of his faith, Paul

4 Schellenberg considers a number of possible objections toward his characterization of religion. Some of them deal with the possible misunderstanding of transmundanity with transcendent. Most of the remaining with the applicability of the notion of ultimization. Neither of these anticipate my objections, since I grant to him that transmundane and transcendent may be read as different and non synonymical notions, while I do not presently address the notion of ultimization. It is not that I concede that ultimization is the sufficient condition for religiosity. Simply, since the content of ultimization practices cannot express necessary features of religion, it suffices to refute that such contents capture the nature of religiosity in order to reject Schellenberg's definition of religion. 
identifies the object of Christian revelation with the unknown God to whom an altar was dedicated. The main deities of the Greek pantheon were not suited to be compared with the extraordinary, transcendent, love-deserving God of Jesus. Actually, while such deities were at hand, the Christian God is far beyond the realm of ordinary experiences. And that is why, Paul compares Him with an unknown God in order to be understood by his audience.

Far from providing a peculiar case, ancient Greeks and Roman deities seem to fit with a common way to understand the ontological status of divine realm, and its relation with personal existences of human beings. By the words of C. Lévi Strauss, the tribal way of thinking constitutes a science of concreteness, according to which deities, spirits, animals, vegetables, and whatever can have a name, are part of a mundane taxonomy. The inclusion of individuals in such taxonomies in virtue of their totemic relationships is constitutive of their personal identity. Consequently, any element belonging to these taxonomies is a possible content of an ordinary experience. Similarly to the case of Greek and Romans deities, what makes the objects of religious rituals a different taxonomical item from daily ones is simply the greater capability to act by those who belong to the former group (Lévi-Strauss 1962).

Such an attitude is not the outcome of an archaic manner of thinking. For example, contemporary examples of a similar practical understanding of religious objects are reported in the anthropological studies by G. Schlemmer with Kulung people from Himalaya (Schlemmer 2014). The basic intuition of his native informant is that the soundness of a religion is verifiable in reason of standards of mundane effectiveness.

A further counterexample to the claim that frequent thoughts of a transmundane reality $(\mathrm{T})$ correctly characterizes religiosity comes from narratives of religious conversion. They provide clear evidence in support of the claim that religious systems of beliefs and practices do not address contents which reside faraway from everyday concerns. On the contrary, conversion is often understood by converted individuals as an immediate and trivial awareness that mundane things stand as their new religion teaches. What raised difficulties in the religion which the converted individual gave up was the incompatibility between her ordinary experience and her religious beliefs. The new religion is felt as a complete description of what the converted have always enjoyed (Harline 2013).

Naturally, I am not claiming that the familiarity and triviality of religious contents are mandatory for religiosity. I am simply pointing at evidence which does not square with Schellenberg's assumption of (T). Certainly, transmundanity of religious contents captures a feature that some religions do have. Strongly transcendent theist religions show an inclination to favour thoughts of God as thoughts of something extraordinary. But such a feature is not a religious universal and is not necessary even for strongly transcendent theist religions (e.g., a literal understanding of Christian prayer in terms of speaking with God the Father is possibly based upon archaic pieces of tribal theologies which are preserved within the Bible; such tribal theologies understand God as a member of the family of the person who prays; conclusion follows: personal prayer in Christianity is a reminiscence of a notion of God as a family member, and give voice to such a religious attitude (Gerstenberger 2001)).

Now, Since Schellenberg claims that $(\mathrm{T})$ is a necessary constituent of any religion (in the technical way he puts all the matter in the second step of his definition: ultimization concerns a transmundane reality), even the anecdotal evidence to which I refer suffices to reject his view.

Second, ultimism characterizes the behaviour of religious individuals as a goal-oriented practice which aims to achieve the most valuable good which can be embodied in human life, that is, salvation (e.g., in the definition of ultimism the ultimate reality is said to be salfivic). But, such a characterization cannot apply to a variety of religions. For example, it is difficult to reconcile a number of strands of Buddhism and Hinduism with the idea that the end of religious rituals is the attainment of a positive future condition. There are no good to be searched for here. It is indeed misleading to depict the religious experience of adherents to these traditions in terms of looking for a state of being which is salvific. In fact, they desire liberation from actualising any state of being, and they do not attribute any value to the future condition of the freed individuals: because when individuals are liberated they will not be anything at all anymore. Liberation is the end of the story. Is this salvation? Is soteriology a 
good category to understand such a kind of religiosity? To my view, equating liberation with salvation is only a deep misunderstanding.

Further, the attainment of an ultimate good in relation to an ultimate reality $(\mathrm{G})$ can be evaluated as a misconception of the purpose of religious practices in another sense too. Consider Rudra, one of the Vedic deities. In the Rig Veda He is described as a ferocious God who kills animals and human beings (Rig Veda, 1.114.7-8; 2.33.15), afflicts children with diseases (Rig Veda 7.46.2), and sends illness to villages (Rig Veda 7.46.3). Sacrifices dedicated to Rudra are certainly officiated in view of a goal. But this goal is not the achievement of a valuable good. On the contrary, it is the hope that the deity will not persecute anymore the participants to the rituals (Rig Veda $2.33 .3-5 ; 7.46 .3-4$ ). Naturally, Rudra also dispenses healing remedies: nonetheless $\mathrm{He}$ is the cause of the illness for which the remedies are asked for. All this highlights a point: the Vedic traditions relating to Rudra do not attest a focus on achieving a good; rather, the goal of rituals is to protect participants from evils caused by the deity.

A similar religious attitude is common to many religions (e.g., religions from Ancient Mesopotamia, Egypt, Greece, Roman Empire, and Pre-Columbian America). Gods are sometimes terrible, frightful and horrendous. Individuals enjoying religious experiences along these lines do not expect any good from their religious commitments: they simply hope that they will not be oppressed by the intentional evils which deities can procure them.

Naturally, many religions give a more comforting reading of the relationship between the divine realm and human beings. But a sympathetic transmundanity-mundanity relation is not a religious universal. Therefore, $(\mathrm{G})$ cannot be a feature all religions entail.

If my arguments are sound, Schellenberg's ultimism turns out to be challenged by a number of counterexamples. It may be the case that a different construal of ultimism is able to reply such criticisms. But, in order to accomplish the task a more historically focused attention to religious examples is required.

\section{Conclusions}

The previous discussion provides arguments against the main strategies for dealing with the notion of religion. Does such discussion provide some positive outcomes too? My intuition is that evidence corroborating the rebuttal of PI, CS, and SS has to play a role in determining the set of requirements for any account of religion which aims at being respectful of empirical findings. The scholarly debate on the definition of religion is a lively and fundamental field of inquiry. Dismantling received notions such as substantivism or functionalism by highlighting the reasons why they do not work, points at what should and should not be pursued by an empirically informed evidential approach to religion.

A seminal consequence of a similar framework of research concerns how to deal with religious diversity. For one hand, religion is a colonial concept, which arose from projecting their own viewpoint on rituals, beliefs, and experiences of others (Smith 1991). For the other, however, the notion of religion seems to have an explanatory grip on a constitutive feature of human experience. Accepting the constitutive role of diversity in the religious domain of discourse, and being able to correctly understand what diversity is, is to answer epistemological constraints which favour a doxastic exchange whose main purpose is to enlarge knowledge and make sense of existence. In this sense, the rejection of problematic concepts within religiosity consists in unveiling rooted prejudices and departing from an unreflective use of traditional assumptions.

My view is that the most important consequence of the refutation of substantivism towards religion can be individuated in the assumption of a methodological imperative to focusing on particularities and anecdoticity. Instead of developing highly abstract theories of religion, the philosophical analysis may add conceptual clarity and argumentative force to current debates in religious studies (Burley 2018). For an empiricist, the path to such an enterprise consists in introducing notions, distinctions, theories, and logical consequences within detailed case studies. 
Funding: This research received no external funding.

Conflicts of Interest: The author declares no conflicts of interest.

\section{References}

Ballanti, Roberto C. 2014. La religione come problema filosofico. Un'analisi dell'Eutifrone di Platone. In Roberto Celada Ballanti, Religione, storia, libertà. Napoli: Liguori Editore, pp. 1-25.

Basinger, David. 2018. Religious Diversity (Pluralism). Edited by Edward N. Zalta. Spring 2018 Edition. Stanford: The Stanford Encyclopedia of Philosophy, Available online: https: / plato.stanford.edu/archives/spr2018/ entries / religious-pluralism/ (accessed on 3 January 2019).

Bellentami, Giulia. 2013. Il tempio di Chidambaram, il luogo del cuore. In Tempio e persona. Dall'analogia al sacramento. Edited by Francesco V. Tommasi. Verona: Edizioni Fondazione Centro Studi Campostrini, pp. 113-23.

Berger, Peter L. 1974. Some Second Thoughts on Substantive versus Functional Definitions of Religion. Journal for the Scientific Study of Religion 13: 125-33. [CrossRef]

Bertini, Daniele. 2018. The anecdotal nature of religious disagreements. International Journal of Philosophy and Theology. [CrossRef]

Bianchi, Ugo. 1975. The History of Religions. Leiden: Brill.

Bogardus, Tomas. 2009. A Vindication of the Equal-Weight View. Episteme 6: 324-39. [CrossRef]

Bogardus, Tomas. 2013. Disagreeing with the Religious Sceptic. International Journal for Philosophy of Religion 74: 5-17. [CrossRef]

Bremmer, Jan N. 1999. The Greek Religion. Oxford: Oxford University Press. [CrossRef]

Burley, Mikel. 2018. Religious Diversity and Conceptual Schemes: Critically Appraising Internalist Pluralism. Sophia.

Cesari, Jocelyne, ed. 2014. Introduction. In The Oxford Handbook of European Islam. Oxford: Oxford University Press, pp. 1-21.

Christensen, David. 2007. The Epistemology of Disagreements: The Good News. The Philosophical Review 116: 187-217. [CrossRef]

Clarke, Peter B., and Peter Byrne. 1993. Religion Defined and Explained. London: Macmillan.

Congregazione per il Culto Divino e la Disciplina dei Sacramenti. 2017. Lettera circolare ai Vescovi sul pane e il vino per l'Eucaristia, Prot. N. 320/17. Available online: http://www.vatican.va/roman_curia/ congregations /ccdds/documents/rc_con_ccdds_doc_20170615_lettera-su-pane-vino-eucaristia_it.html (accessed on 12 February 2018).

Dolce, Lucia. 2010. The Contested Space of Buddhist Public Rituals: The Shûnie of Tōdaiji. In Grammars and Morphologies of Ritual Practices in Asia. Edited by Axel Michaels, Anand Mishra, Lucia Dolce, Gil Raz and Katja Triplett. Wiesbaden: Harrasowitz Verlag, pp. 433-58.

Elga, Adam. 2007. Reflection and Disagreement. Nous 41: 478-502. [CrossRef]

Eliade, Mircea. 1948. Traité d'histoire des Religions. Paris: Payote.

Feldman, Richard. 2006. Epistemological Puzzles About Disagreements. In Epistemology Futures. Edited by R. Hetherington. Oxford: Oxford University Press, pp. 194-214.

Feldman, Richard. 2007. Reasonable Religious Disagreements. In Philosophers Without Gods: Meditations on Atheism and the Secular Life. Edited by L. Antony. Oxford: Oxford University Press, pp. 194-214.

Finley, Moses I. 1963. The Ancient Greeks. London: Chatto and Windus.

Gerstenberger, Erhard S. 2001. Theologien im Alten Testament. In Pluralität und Synkretismus alttestamentalischen Gottesglauben. Stuttgart: Verlag W.Kohlhammer.

Grillo, Andrea. 2005. Genealogia eucaristica della Chiesa, una riscoperta conciliare alla prova. Breve itinerario critico da Mediator dei a Redemptionis Sacramentum. Reportata. Passato e presente della teologia, 3. Available online: http:/ / mondodomani.org/reportata/grillo01.htm (accessed on 12 February 2018).

Harline, Craig. 2013. Conversions. Two Family Stories from the Reformation and the Modern America. Yale: Yale University Press.

Hick, John. 2004. An Interpretation of Religion. Human Responses to the Transcendent. New Haven and London: Yale University Press. 
Kaya, Ayhan. 2014. Islamophobia. In The Oxford Handbook of European Islam. Edited by Jocelyne Cesari. Oxford: Oxford University Press, pp. 745-69.

Legenhausen, Muhammad. 1999. Islam and Religious Pluralism. London: Al-Hoda Publishers and Distributors. Lévi-Strauss, Claude. 1962. La pensée sauvage. Paris: Librairie Plon.

Long, Jeffery. 2014. Jains. In Religions in Focus: New Approaches to Tradition and Contemporary Practices. Edited by Graham Harvey. Oxon and New York: Routledge, pp. 216-36.

Mantzillas, Dimitrios. 2016. Sacrificial Animals in Roman Religions. Rules and Exception. In Animals in Greek and Roman Religion and Myth. Edited by Patricia A. Johnston, Attilio Mastrocinque and Sophia Papaioannou. Newcastle upon Tyne: Cambridge Scholars Publishing, pp. 19-38.

Mazza, Enrico, ed. 2010. L'altare come luogo della comunione. Un problema di oggi alla luce della storia. In Rendere grazie. Miscellanea eucaristica per il 70o compleanno. Bologna: EDB Edizioni Dehoniane, pp. 397-413.

Mazza, Enrico. 2012. La doctrine médiévale de l'eucharistie et les Pères de l'Église: Continuité ou rupture? Revue de Droite Canonique 62: 53-76.

McKim, Robert. 2012. On Religious Diversity. Oxford: Oxford University Press.

Montgomery, David. 2015. On Muslims and the Navigation of Religiosity: Notes on the Anthropology of Islam. In Ashgate Research Companion to Anthropology. Edited by Andrew Strathern and Pamela Stewart. Oxford: Routledge, pp. 227-54.

Murray, Oswyn. 1993. La città greca. Torino: Einaudi.

Plantinga, Alvin. 2000. Pluralism: A Defense of Religious Exclusivism. In The Philosophical Challenge of Religious Diversity. Edited by Philip L. Quinn and Kevin Meeker. New York and Oxford: Oxford University Press, pp. 172-92.

Quinn, Philip L., and Kevin Meeker, eds. 2000. The Philosophical Challenge of Religious Diversity. New York and Oxford: Oxford University Press.

Radhakrishnan, Sarvepalli. 1957. The Hindu View of Life. Upton Lectures Delivered at Manchester College. Oxford 1926. New York and London: Macmillan-G. Allen.

Ratzinger, Joseph. 1986. Theologie und Kirche. Communio 15: 515-33.

Ruhmkorff, Samuel. 2013. The Incompatibility Problem and Religious Pluralism Beyond Hick. Philosophy Compass 8: 510-22. [CrossRef]

Schellenberg, J. L. 2005. Prolegomena to a Philosophy of Religion. Ithaca and London: Cornell University Press.

Schlemmer, Grégoire. 2014. Pluri-religious Affiliation and the Opennes of a Local Religion to the Universal: A Case Study from the Himalaya. Paper presented at the 23rd European Conference for South East Asia, Zurich, Switzerland, July 23-26; Available online: https: / / www.academia.edu/11891612/Pluri-religious_Affiliation_and_the_Openness_of_a_Local_Religion_to_ the_Universal_A_Case_Study_from_the_Himalayas (accessed on 3 January 2019).

Smith, Wilfred C. 1991. The Meaning and End of Religion. Minneapolis: Fortress Press.

Snell, Bruno. 2009. Die Entdeckung des Geistes. Studien zur Entstehung des europäischen Denken bei den Griechen. Göttingen: Vandenhoeck and Ruprecht.

Suzuki, Daisetz Teitaro. 1964. An Introduction to Zen Buddhism. New York: Groove Press Inc.

van Inwagen, Peter. 2010. We're right. They're wrong. In Disagreements. Edited by Richard Feldman and Ted A. Warfield. Oxford: Oxford University Press.

Vernant, Jean Pierre. 1962. Les origines de la pensée grecque. Paris: Presses Universitaires de France.

Vernant, Jean Pierre. 1996. Mythe et pensée chez les Grecs. Etudes de psychologie historique. Paris: Éditions La Découverte.

Warner, R. Stephen. 2008. Parameters of Paradigms: Toward a Specification of the U.S. Religion Market System. Nordic Journal of Religion and Society 21: 129-46.

Wittgenstein, Ludwig. 2001. Philosophical Investigations. The German Text, with a Revised English Translation. Translated by Gertrude Elizabeth Margaret Anscombe. Malden and Victoria: Blackwell Publishing.

(C) 2019 by the author. Licensee MDPI, Basel, Switzerland. This article is an open access article distributed under the terms and conditions of the Creative Commons Attribution (CC BY) license (http:/ / creativecommons.org/licenses/by/4.0/). 